among IDUs in this part of the country is alarmingly high and second only to north-eastern parts of India. HIV prevalence rate in more than 13\% persons has been reported in Punjab and Chandigarh as per the 2006 data from NACO. ${ }^{[1]}$ Therefore, we carried out this study to determine the seroprevalence rate of HIV in persons referred to the Department of Microbiology at Amritsar, Punjab between January 2006 and December 2007. This included 715 IDUs, attending ICT Clinic. Of these 712 were males and only 3 were females. They were tested for HIV-I and HIV-2 antibodies according to NACO guidelines. Out of 715 patients, 621 were in the age group of 21-50 years and most of them were married, which is in accordance with the study of Singh et al. ${ }^{[2]}$ The serology results showed that a total of $314(43.90 \%)$ were reactive for HIV-I antibodies. The incidence in the present study is higher than earlier reported incidence in $1997(7.5 \%)^{[3]}$ and $2005(9.6 \%)^{[4]}$ from the same center. Since 86.15\% of the clients were unskilled persons, this can explain the high incidence. Also 14.8\% were mobile persons, which is another known risk factor. Our $52.29 \%$ clients gave history of needle sharing, while $27.57 \%$ persons admitted to have multiple sex partners (MSP), an another behavioral risk factor. ${ }^{[5]}$ Since Amritsar being the border city and is the seat of international drug trafficking providing home to a large number of young people prone to drug addiction, it is feared that this region might face sharp rise in HIV prevalence in the near future. Hence, urgent targeted interventions are required.

Usha Arora

Department of Microbiology, Govt. Medical College, Amritsar, India

Address for correspondence: Dr. Usha Arora, E-mail: ushar_ora@yahoo.co.in

DOI: 10.4103/0974-2727.59707

\title{
REFERENCES
}

\section{Seroprevalence of HIV Among Intravenous Drug Users in Amritsar: Risk Factors and Risk Behavior}

\author{
Sir, \\ One of the major factors behind the spread of HIV in \\ the country is injecting drug use (IDU). HIV infection
}

1. Ambekar A, Tripathi BM. For SPYM size estimation of injecting drug use in Punjab and Haryana under the pear led intervention. UNAIDS. Publication New Delhi, 2008:6-7.

2. Singh YN, Joshi R, Rustogi G. Truck drivers their possible role in dissemination of HIV to rural India. Abstract book $2^{\text {nd }}$ International conference of AIDS in Asia Pacific 1992;626:191.

3. Mohan U, Jindal N, Kaur M. Prevalence of human immunodeficiency virus among intravenous users in Amritsar. J Med Microbiol 1998;16:105-7.

4. Tiwari R, Aggarwal A, Devi P. Seroprevalence of hepatitis B, hepatitis C and human immunodeficiency viruses amongst drug users in Amritsar. Indian J Med Microbiol 2006;24:151-2.

5. Sarkar S, Das N, Panda S, Naik TN, Sarkar K, Singh BC, et al. Rapid spread of HIV among injecting drug users in north-eastern states of India. Bull Narc 1993;45:91. 